\title{
Malignt melanom - diagnostikk, behandling og oppfølging i Norge
}

\begin{abstract}
BAKGRUNN Hyppigheten av maligne melanomer i Norge er blant de høyeste i verden og stigende. Omtrent 1500 personer får årlig diagnosen malignt melanom i Norge. Korrekt kirurgisk primærbehandling kurerer 80-90\%, mens 10-20\% opplever tilbakefall. Behandlingen av et metastatisk malignt melanom er betydelig endret de siste 1-2 år grunnet kliniske erfaringer med nye medikamenter. Den foreliggende publikasjonen gir en oppdatert oversikt over behandlingen av maligne melanomer i Norge.
\end{abstract}

KUNNSKAPSGRUNNLAG Artikkelen er basert på et søk i PubMed samt på forfatternes egen forskning og kliniske erfaringer.

RESULTATER Etter flere tiår nesten uten endringer i behandlingen av maligne melanomer har vi sett en positiv utvikling de siste par årene. Nye behandlingsmetoder for malignt melanom med fjernspredning har vist gunstige resultater hos utvalgte pasienter og blir nå etablert på kreftavdelingene i Norge.

FORTOLKNING Rask og korrekt kirurgisk primærbehandling er det som kurerer flest pasienter med malignt melanom. Nye medikamenter gir håp til utvalgte pasientgrupper med metastatisk sykdom. Flere nyere typer målrettet behandling testes ut i kliniske studier i Norge og ellers i verden.

I Norge registreres hvert år ca. 1500 tilfeller av malignt melanom (1). Tidlig diagnose og adekvat kirurgisk behandling kurerer mange pasienter $(80-90 \%)$. Av dem som blir operert, vil ca. $10-20 \%$ oppleve lokalt/regionalt tilbakefall eller fjernspredning (2). Disse trenger rask vurdering og behandling. Cellegiftbehandling vil være standard for de fleste pasienter med fjernspredning, men noen vil kunne tilbys nyere typer systembehandling som ofte er mer målrettet og effektiv enn cellegift. Nyere medikamenter gir håp til denne pasientgruppen etter mange års stillstand i behandlingstilbudet. Denne publikasjonen er tenkt som en oppsummering av den etablerte behandlingen og de nyeste trendene innen diagnostikk og behandling av pasienter med føflekkreft i Norge.

\section{Kunnskapsgrunnlag}

Artikkelen bygger på et søk i PubMed etter relevante publikasjoner i tidsrommet 1.1. 2000-1.4. 2013. Følgende stikkord ble brukt i søket: «malignant melanoma» (alene og i kombinasjon med følgende tilleggsstikkord:) «surgery», «sentinel node procedure», «chemotherapy», «immunotherapy», «radiation», «molecular biology», «BRAF», «CTLA-4», og «MEK». I tillegg bygger artikkelen på forfattergruppens samlede kliniske og forskningsmessige erfaringer knyttet til malignt melanom.

\section{Epidemiologi, forebygging og solariebruk}

Siden Kreftregisteret ble opprettet i 1952 er forekomsten av malignt melanom i hud mer enn åttedoblet (1). I aldersgruppen 15-54 år er dette nå den nest hyppigst forekommende kreftformen for begge kjønn samlet. I 1953 var den aldersjusterte insidensraten (antall tilfeller per 100000 per år) for kvinner og menn henholdsvis 1,9 og 2,2, mens tilsvarende tall for 2010 var 19,6 og 19,0 (3). Den største økningen ser vi i aldersgruppen over 60 år, særlig for menn. Forekomsten av malignt melanom er mer enn dobbelt så hyppig i Sør-Norge som i Nord-Norge. Det tilskrives ulik soleksponering (dose av ultrafiolett (UV)-stråling), som er den viktigste kjente årsaken til utviklingen av malignt melanom (4). Intermitterende og intens eksponering som kan medføre forbrenning regnes som spesielt skadelig. Best overlevelse har pasienter med lokal sykdom. Langtidsoverlevelsen ved melanom $\mathrm{i}$ avansert stadium er lav og marginalt bedret over tid.

Primær forebygging innebærer derfor beskyttelse mot intens eksponering for sol som kan medføre solforbrenning. Kreftforeningens solvettregler anbefaler pauser fra solen mellom kl 11 og kl 15, bruk av beskyttende plagg og solkrem med minst faktor 15 . I en metaanalyse utført av en internasjonal arbeidsgruppe i samarbeid med World Health Organization (WHO) har man dessuten dokumentert økt risiko for malignt melanom for solariumbrukere, og på denne bakgrunn frarådes bruk av solarium (5). Sekundær forebygging oppnås gjennom økt bevissthet og kunnskap i befolkningen.

\section{Kliniske kjennetegn}

Kliniske funn ved malignt melanom varierer. Anamnese sammenholdt med klinisk undersøkelse og eventuelt dermatoskopi vil kunne

\author{
Jürgen Geisler \\ juergen.geisler@medisin.uio.no \\ Kreftavdelingen \\ Akershus universitetssykehus \\ og \\ Institutt for indremedisin \\ Universitetet i Oslo \\ Ingeborg M. Bachmann \\ Hudavdelingen \\ Haukeland universitetssykehus \\ og \\ Institutt for indremedisin \\ Universitetet i Bergen

\section{Marta Nyakas} \\ Avdeling for kreftbehandling \\ Oslo universitetssykehus, Radiumhospitalet
}

\section{Per Helsing}

Hudavdelingen

Oslo universitetssykehus, Rikshospitalet

Hans E. Fjøsne

Kirurgisk klinikk

St. Olavs hospital

\section{Lovise Olaug Mæhle}

Avdeling for medisinsk genetikk

Oslo universitetssykehus, Radiumhospitalet

\section{Steinar Aamdal}

Avdeling for kreftbehandling

Oslo universitetssykehus, Radiumhospitalet

\section{Nils A. Eide}

Øyeavdelingen

Oslo universitetssykehus, Ullevål

Henrik L. Svendsen

Plastikkirurgisk avdeling

Haukeland universitetssykehus

Oddbjørn Straume

Onkologisk avdeling

Haukeland universitetssykehus

\section{Trude E. Robsahm}

Institutt for populasjonsbasert kreftforskning Kreftregisteret

\section{Kari D. Jacobsen}

Avdeling for kreftbehandling

Oslo universitetssykehus, Radiumhospitalet

\section{Lars A. Akslen}

Gades institutt

Haukeland universitetssykehus

Se også kunnskapsprøve

på www.tidsskriftet.no/quiz

Podkast på www.tidsskriftet.no

Engelsk oversettelse på www.tidsskriftet.no 


\section{HOVEDBUDSKAP}

Hvert år får ca. 1500 pasienter i Norge diagnosen malignt melanom, og 80-90\% av disse vil bli helbredet med tidlig og adekvat kirurgi

Pasienter med lokalt tilbakefall kan i noen tilfeller helbredes dersom de får tidlig behandling med kirurgi, ev. etterfulgt av strålebehandling

Standard cellegiftbehandling kan i korte perioder stabilisere sykdommen hos $5-10 \%$ av pasientene som har metastatisk sykdom

Alvorlige bivirkninger og høye kostnader ved de nye medikamentene har ført til en omfattende diskusjon i norske og utenlandske medier bidra til at diagnosen mistenkes. $\mathrm{ABCD}(\mathrm{E})$ regelen (4) er nyttig for en klinisk vurdering av hudlesjoner (ramme 1). Pigmenterte lesjoner som avviker fra pasientens øvrige nævuser («den stygge andungen») er viktig diagnostisk og kan være et melanomsensitivt tegn (6). For pasienter i høyrisikogrupper kan helkroppsfotografier være aktuelt for å følge utviklingen av nævuser og for å oppdage nye lesjoner tidlig. Diagnosen baseres på histopatologisk undersøkelse ved eksisjonsbiopsi av lesjonen. Eksisjonsbiopsi kan ofte utføres av allmennlege eller hudlege. Ved spesielt store lesjoner eller beliggenhet på kosmetisk vanskelige områder bør eksisjon foretas av kirurg/plastikkirurg.

\section{Histopatologisk vurdering}

Diagnosen malignt melanom stilles ved histopatologisk undersøkelse (fig 1). Melanom klassifiseres i følgende hovedtyper: superfisielt spredende melanom, nodulært melanom, lentigo maligna-melanom, og akralt lentiginøst melanom (2) (fig 2). Det finnes også sjeldnere varianter, som desmoplastisk melanom. Bortsett fra nodulære melanomer kan alle hovedtypene foreligge som in situlesjoner (ikke-invasive) eller invasive. Diagnosen «nævuscelletumor med atypi» indikerer at man ikke kan utelukke et melanom, og dette tilsier ofte at lesjonen behandles som melanom (2). Flere karakteristika har prognostisk og behandlingsmessig betydning. De viktigste inngår i klassifikasjonen av maligne melanomer som obligate variable (7): tykkelse, ulcerasjon og mitosetall.

Vaktpostlymfeknutediagnostikk innføres nå i Norge for 2-4 mm tykke melanomer. Prosedyren og nytteverdien forklares i det nasjonale handlingsprogrammet for maligne melanomer som nylig ble publisert av Helsedirektoratet (1).

\section{Genetikk}

Personer med lys hudtype og/eller mange føflekker (f.eks. som ved atypisk nævus-syndrom) er mer disponert for malignt melanom enn andre (2). Familiær opphopning av malignt melanom kan skyldes f.eks. nedarvede genfeil i $C D K N 2 A$ - eller $C D K 4$-genet $(8,9)$, såkalt dominant arvelig melanom. Det drives et omfattende internasjonalt samarbeid for å finne andre gener som kan føre til arvelige typer malignt melanom i regi av konsortiet Genomel (10). Nytten av systematiske kontroller av personer med familiær opphopning av føflekkreft er vist i kliniske studier (11). Ved mistanke om arvelig disposisjon, f.eks. ved tre maligne melanomer blant første- eller annengradsslektninger (rule of threes) bør personene henvises til en genetisk avdeling (2). Personer med påvist genfeil følges med årlige kontroller ved hudavdeling, eventuelt kreftavdeling (1).

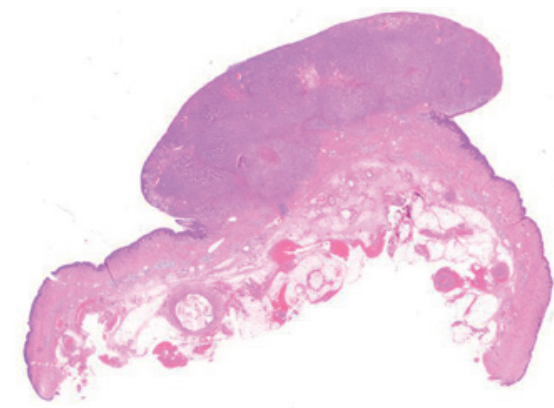

a

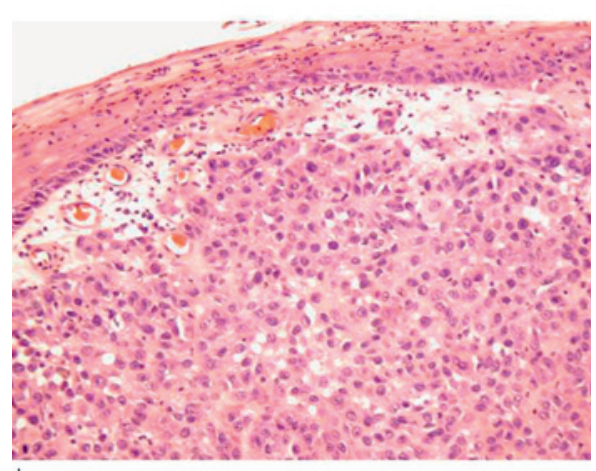

Figur 1 al Polypøst malignt melanom av nodulær subtype, b) Diffus (udifferensert) vekst av grovt atypiske celler, assosiert med økt kardanning. Foto Lars A. Akslen

\section{Kirurgi}

Kirurgisk behandling er foreløpig den eneste potensielt kurative behandlingen for malignt melanom, og en korrekt prosedyre er derfor ekstremt viktig.

\section{Primærbehandling}

Eksisjonsbiopsi av en melanomsuspekt hudlesjon skal gjøres ved at hele tumor fjernes med 2-5 mm margin ut i normal hud med en pute av subkutant fett (2) (fig 3). Biopsien sendes alltid til histologisk undersøkelse. Resultatet danner grunnlag for videre kirurgisk behandling. Insisjonsbiopsi, stansebiopsi og laserbehandling av melanomsuspekte hudlesjoner anbefales ikke, da disse

RAMME 1

$A B C D(E)$-regelen) for klinisk vurdering av hudlesjoner (4)

A for Asymmetri

B for Begrensning

C for Colour $=$ farge

D for Diameter (> $6 \mathrm{~mm}$ )

E for Endring 


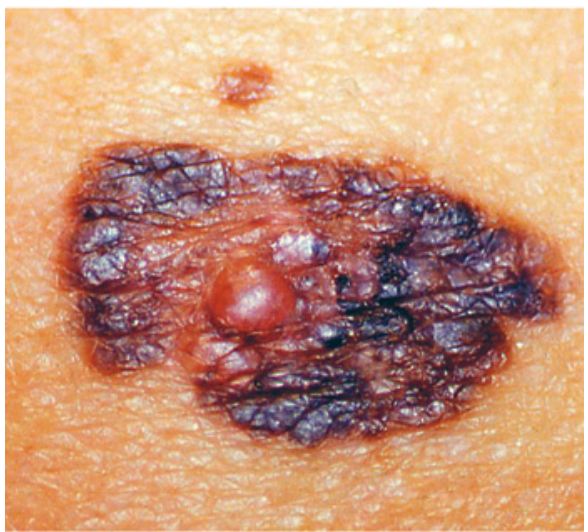

a

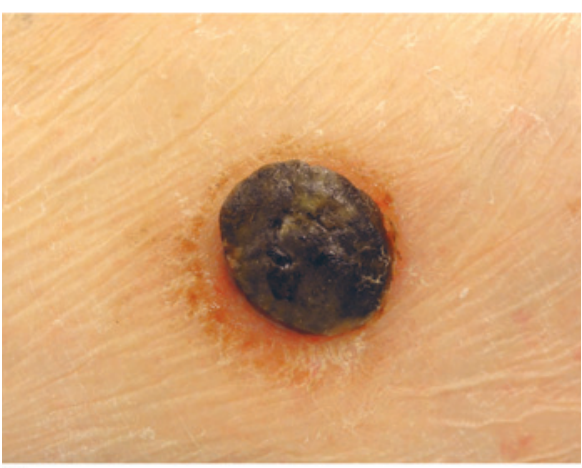

b

Figur 2 Hovedtyper av kutane primære maligne melanomer: al Superfisielt spredende malignt melanom og b) nodulært malignt melanom. Foto Per Helsing

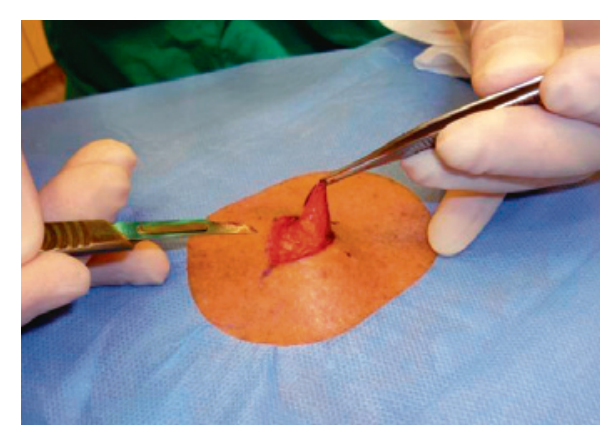

Figur 3 Kirurgi ved primære maligne melanomer i hud. Foto Henrik L. Svendsen

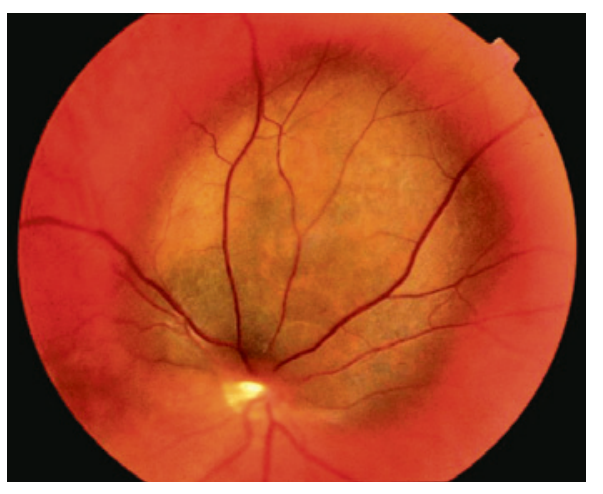

Figur 4 Malignt melanom med utgangspunkt i øyet. Foto Nils A. Eide prosedyrene ofte umuliggjør bedømmelse av tumortykkelsen. Primæreksisjonen kan foregå i primærhelsetjenesten. Ved spesielle lokalisasjoner er det naturlig å henvise pasienten videre til hudlege eller kirurg.

\section{Utvidet eksisjon}

De siste årene har de anbefalte eksisjonsavstandene for utvidet eksisjon ved histologisk påvist malignt melanom blitt redusert. Den utvidede eksisjonen bør gjøres ned til underliggende fascie. Det er den klinisk målte avstanden fra tumor/arret som gjelder, og ikke marginen i det fikserte materialet. De fleste defektene som oppstår med dagens anbefalinger, kan lukkes direkte, dvs. uten hudtransplantat. Anbefalte hudmarginer ved utvidet eksisjon i Norge er gjengitt i tabell 1. Anbefalingene baserer seg på store, prospektive, randomiserte, kliniske studier der man har sammenlignet overlevelse og lokale tilbakefall med ulike eksisjonsmarginer (12). Fjerning av maligne melanomer i ansikt, øre, fingre og tær samt fotsåle er komplisert og krever spesielle kirurgiske hensyn (1).

\section{Ved mistanke om lokalt residiv og metastaser}

Pasienter med residiv skal henvises til kirurgisk avdeling som opererer pasienter med malignt melanom, som oftest en plastikkirurgisk avdeling. Behandlingen er kirurgisk så langt det kan gjennomføres. Før operasjon utredes pasienten med finnålsaspirat (fineneedle aspiration cytology, FNAC) hvis mulig samt med bildediagnostikk (ultralyd/ CT/PET-CT). Utvidet eksisjon, lymfeknutetoalett og eksisjon av utvalgte fjernmetastaser kan være aktuelle operative inngrep.

\section{Vaktpostlymfeknuter}

Vaktpostlymfeknuteundersøkelse (sentinel node procedure) i primærdiagnostikk av kutane maligne melanomer er nå i utstrakt bruk $(13,14)$. Inklusjon i internasjonale studier betinger ofte at vaktpostlymfeknuteundersøkelser er utført. Prosedyren er i Norge aktuell hos pasienter med ekstremitetsmelanomer med tumortykkelse 2-4 mm uten ulcerasjon (stadium IIa, pT3a), eller tumortykkelse 1-2 mm med ulcerasjon (stadium IIa, pT2b) (1). Ved tynne melanomer er risikoen for lymfeknutemetastaser mindre, men det vurderes også i Norge å utføre prosedyren hos pasienter med tumortykkelse $1-2 \mathrm{~mm}$. I tillegg vurderer man å utføre prosedyren også hos pasienter med melanomer på truncus. Prosedyren bør utføres samtidig med utvidet eksisjon. Melanompasienter som er aktuelle for lymfeknutekartlegging bør undersøkes i aksille eller lyske med ultralyd. Pasienter med klare lymfeknutemetastaser kan gå til direkte lymfeknutetoalett. Effekten av en vaktpostlymfeknutediagnostikk på overlevelse er uavklart. Funn av metastase i vaktpostlymfeknute påvirker ikke overlevelse, men øker kun sykdomsfritt intervall $(15,16)$.

\section{Oppfølging etter kirurgi}

Metastaser fra malignt melanom ses hyppigst til regionale lymfeknuter, mens fjernmetastaser forekommer i hud, lunger, lever, skjelett, mage/tarm og hjerne. De fleste tilbakefall skjer i løpet av de første tre årene (1). I sjeldne tilfeller er det beskrevet mer enn 30 års latenstid for metastasene manifesterer seg (2). I de fleste tilfeller kan kontroller utføres av fastlegen. Ved forekomst av utbredte atypiske nævuser eller ved familiær risiko for malignt melanom bør enkelte av kontrollene utføres av hudlege med samtidig dermatoskopi av øvrige pigmenterte lesjoner. Risiko for tilbakefall er relatert til primærtumors tykkelse, og oppfølgingen bør tilpasses dette, se detaljer hos Robsahm og medarbeidere (1).

\section{Lokal cellegiftbehandling}

Pasienter med multiple (inoperable) metastaser til (utelukkende) en ekstremitet kan være egnet for en intensiv lokal cellegiftbehandling (isolated limb perfusion) (17). Det anvendes hypertermi i kombinasjon med intraarteriell melfalanhydroklorid enten alene eller i kombinasjon med tumornekrosefaktor (TNF). Pasienter som skal vurderes for denne behandlingen skal henvises direkte til Oslo universitetssykehus, Radiumhospitalet, som har landsfunksjon for slik behandling i Norge.

\section{Systembehandling}

Ingen adjuvant behandling har inntil nylig vist seg å være livsforlengende. For å forlenge overlevelsen har alt fra cellegifter og ulike målrettede behandlinger til forskjellige former for immunterapi og kombinasjoner vært prøvd ut, uten at dette har bedret overlevelsen. Dakarbazin, temozolomid, vinblastin, og cykloheksyl-kloroetyl-nitrosourea (CCNU) er blitt stående som «standardterapi», men alle har svært lave responsrater og ingen har vist seg å være livsforlengende (18-21). De siste årene er det imidlertid blitt utviklet helt nye medikamentelle alternativer som radikalt har forandret behandlingen av malignt melanom.

\section{Immunterapi}

Ipilimumab er et humant monoklonalt antistoff mot cytotoksisk T-lymfocytt antigen-4 (CTLA-4) (22). Normalt nedregulerer CTLA4 T-celle-aktivering. Ipilimumab potenserer dermed T-celle-aktivering. Ipilimumab og glykoprotein-peptid-vaksine (Gp 100-vaksine) ble testet $i$ en trearmet studie (23). Studien inkluderte pasienter som hadde inoperabelt stadium III/IV-melanom med progresjon av sykdommen etter systemisk behandling 
(23). Ipilimumab ga, som det første medikamentet noensinne, signifikant forlenget overlevelse. Hos over $20 \%$ av pasientene gir ipilimumab langtidsvirkning som kan vare i flere år. Bivirkningene ved bruk av medikamentet er autoimmune sykdommer. De vanligste er kolitt, hepatitt, hypofysitt og dermatitt (23). På grunnlag av denne studien har U.S. Food and Drug Administration (FDA) og European Medicine Agency (EMA) godkjent ipilimumab for behandling av metastaserende malignt melanom. Markedsføringstillatelse ble gitt under forutsetning av at produsenten gjennomførte en fase IV-studie. En slik studie er nå i gang i Europa. I Norge vil det i stedet, etter pålegg fra Helse- og omsorgsdepartementet, gjennomføres en nasjonal fase IVforskningsstudie. Frem til studien kommer i gang, etter godkjenning av Statens legemiddelverk og etisk komité, skal alle egnede pasienter med metastaser fra malignt melanom få muligheten til behandling med ipilimumab. Medikament- og studiekostnader skal dekkes over egen bevilgning over statsbudsjettet.

Kombinasjonsbehandling med ipilimumab og nivolumab (PD-1-antistoff) testes øyeblikket i en fase III-studie etter meget lovende resultater i en fase I-studie (24).

\section{Nyere, målrettet behandling}

Serin-treonin-protein-kinasen BRAF (v-raf murine sarcoma viral oncogene homolog B1) er mutert i mange maligne melanomer. Aktiverende mutasjoner (f.eks. BRAF-V600E) i tumorceller finnes hos ca. $50 \%$ av alle melanompasienter i Norge. BRAF-hemmeren PLX4032 (vemurafenib) virker selektivt på celler som har BRAF-V600E-mutasjoner. I fase I-II-studier har vemurafenib vist responsrater på ca. $50 \%(25,26)$.

To multisenter fase III-studier med vemurafenib eller dabrafenib versus dakarbazin som førstelinjebehandling hos pasienter med BRAF-V600E-positive svulster har vist at vemurafenib gir signifikant forlenget overlevelse, mens dabrafenib gir signifikant forlenget progresjonsfri overlevelse. Begge medikamentene hadde høye responsrater $(27,28)$.

De vanligste bivirkninger var utslett, alopesi, fotosensitivitet, fatigue, artralgi og keratokantom/plateepitelkarsinom i hud. Dersom man kombinerer BRAF-hemmere med MEK-inhibitorer, kan responsraten økes ytterligere, mens hudkomplikasjonene reduseres (29).

Den kliniske effekten av BRAF-hemmere kommer i løpet av dager til noen få uker, dvs. raskere og alt $i$ alt med kort varighet sammenliknet med immunterapi.

Både vemurafenib og dabrafenib er godkjent av U.S. Food and Drug Administration og European Medicine Agency. Begge medikamenter appliseres i tablettform og kan skrives ut etter søknad til HELFO om individuell refusjon.

\section{Strålebehandling}

Stråleterapi har ingen plass i behandlingen av primære maligne melanomer, med unntak av lokalavansert malignt melanom og ved melanomer i øyet, der spesialisert stråleterapi kan gi kurativ effekt og spart øyefunksjon (30). Strålebehandling (50 kV rtg) gis også ved større lentigo maligna-melanomer i ansiktet.

Postoperativ strålebehandling bør vurderes der det foreligger usikker radikalitet og der reoperasjon ikke er aktuelt, for eksempel etter ekstirpert lokalt residiv og etter lymfeknutetoalett der det ikke foreligger tumorfrie reseksjonsflater og eventuelt ved ekstranodulær tumorvekst. Studier tyder på at pasienter med melanom i hode-hals-regionen og lymfeknutemetastaser på halsen, særlig med perinodal tumorvekst, kan ha nytte av postoperativ strålebehandling (31). Det foreligger imidlertid ikke dokumentert effekt på overlevelse av postoperativ strålebehandling etter lymfeknutetoalett.

Strålebehandling kan gi god palliasjon og lokal kontroll av inoperable metastaser som ellers ville gi betydelige lokale problemer (2).

Ved metastaser fra malignt melanom bør stråleterapi vurderes i følgende situasjoner:

- Hudmetastaser som ikke kan fjernes kirurgisk og som er symptomgivende

- Skjelettmetastaser som forårsaker smerter og/eller frakturfare

- Metastaser som komprimerer eller truer viktige strukturer, for eksempel medulla spinalis, større nerver eller nerverøtter og sentrale luftveier

- Hjernemetastaser. Ved 1-3 hjernemetastaser der kirurgi ikke er aktuelt bør stereotaktisk strålebehandling vurderes. Det ses forbigående lokal kontroll hos $85-90 \%$ av pasientene som får denne behandlingen (7). Oftest har pasienten multiple hjernemetastaser. Det vil da være aktuelt å strålebehandle hele hjernen. Det oppnås da symptomatisk bedring hos $60-70 \%$ av pasientene (2)

- Solitære lunge- eller levermetastaser som er egnet for stereotaktisk strålebehandling (se nasjonale retningslinjer for detaljer) (1)

\section{Melanomer i øyet og andre sjeldne melanomer}

Av alle melanomer i kroppen oppstår 5\% i øyet, inkludert naboområdene konjuktiva, orbita og øyelokk (1). Uveale melanomer er den vanligste primære maligne øyetumoren hos voksne (fig 4). Samtidig er denne lokalisasjonen den nest hyppigste for et melanom (etter kutane melanomer). Svulsten kan være lokalisert til iris $(5 \%)$, corpus ciliare $(10 \%)$ eller choroidea (85\%) (1). Insiden-
Tabell 1 Anbefalte hudmarginer ved utvidet eksisjon i Norge (1)

\begin{tabular}{|c|c|}
\hline $\begin{array}{l}\text { Type melanom/ } \\
\text { Breslow-tykkelse }\end{array}$ & $\begin{array}{l}\text { Eksisjonsbredde } \\
\text { (in vivo) }\end{array}$ \\
\hline In situ/lentigo maligna & $0,5 \mathrm{~cm}$ \\
\hline$\leq 1 \mathrm{~mm}$ & $1 \mathrm{~cm}$ \\
\hline $1,1-2 \mathrm{~mm}$ & $1 \mathrm{~cm}$ \\
\hline $2,1-4 \mathrm{~mm}$ & $2 \mathrm{~cm}$ \\
\hline$>4 \mathrm{~mm} /$ desmoplastisk & $2-3 \mathrm{~cm}$ \\
\hline
\end{tabular}

sen av uveale melanomer er 5-8 per million innbyggere/år, dvs. ca. 30-40 nye tilfeller per år i Norge (1).

På tross av fremskritt i diagnostikk samt effektiv laserbehandling har mortaliteten ved uveale melanomer vært uendret de siste 50 årene (1). Mortaliteten er i uselekterte materialer opp til $50 \%$ etter ti år. Ved uvealt melanom må det i løpet av to uker gjøres malignitetsutredning i form av en nøye klinisk undersøkelse, ultralyd abdomen, røntgen thorax, leverfunksjonstester og vanlig blodstatus. Prognosen er vanskelig å stille på individnivå. Symptomene ved uvealt malignt melanom er uspesifikke og avhenger av svulstens lokalisasjon i øyet.

I dag er episkleral brakyterapi den behandlingen som er best dokumentert og mest benyttet internasjonalt. Ifølge litteraturen kan opp imot $90 \%$ av dem som blir behandlet regne med å ha sitt eget øye etter ti år, kosmetisk pent og uten vesentlig ubehag (1). Strålekilden sys fast utenpå sklera, nøyaktig svarende til det stedet der svulsten er lokalisert inne i øyet.

Det er to sentre i Norge som er ansvarlige for diagnostikk, behandling og oppfølging av alle maligne intraokulære svulster (Oslo universitetssykehus, Ullevål og Haukeland Universitetssykehus).

Bare $2 \%$ av pasientene har påvisbare metastaser på diagnosetidspunktet (1). Leveren er det hyppigst rammede og mest avgjørende organet ved metastasering.

For behandling av andre, sjeldne lokalisasjoner av primære maligne melanomer (slimhinner i hode-hals-regionen, tynntarm, genitalia etc.) se Nasjonale retningslinjer for diagnostikk, behandling og oppfølging av maligne melanomer (1).

Artikkelen utgår fra Norsk Melanom Gruppe, der alle forfatterne er medlemmer. Alle forfatterne har også bidratt til Helsedirektoratets retningslinjer for diagnostikk, behandling og oppfølging av maligne melanomer (1). 


\section{Jürgen Geisler (f. 1963)}

er dr.med., dr.philos. og spesialist i onkologi og stråleterapi. Han arbeider som overlege og professor.

Forfatter har fylt ut ICMJE-skjemaet og oppgir ingen interessekonflikter.

\section{Ingeborg M. Bachmann (f. 1969)}

er spesialist i hud-og veneriske sykdommer. er overlege og førsteamanuensis.

Forfatter har fylt ut ICMJE-skjemaet og oppgir ingen interessekonflikter.

\section{Marta Nyakas (f. 1968)}

er spesialist i onkologi, arbeider som overlege og har ansvar for melanomstudier.

Forfatter har fylt ut ICMJE-skjemaet og oppgir ingen interessekonflikter.

\section{Per Helsing (f. 1958)}

er spesialist i hud- og veneriske sykdommer og overlege. Han har overordnet ansvar for den dermatologiske oppfølgingen av pasienter med familiært malignt melanom og organtransplanterte pasienter ved Rikshospitalet.

Forfatter har fylt ut ICMJE-skjemaet og oppgir ingen interessekonflikter.

\section{Hans E. Fjøsne (f. 1948)}

er dr.med. og spesialist i generell kirurgi og bryst- og endokrinkirurgi. Han arbeider som avdelingsoverlege og har bistilling som professor ved Institutt for kreftforskning og molekylær medisin ved Norges teknisk-naturvitenskapelige universitet.

Forfatter har fylt ut ICMJE-skjemaet og oppgir ingen interessekonflikter.

\section{Lovise Olaug Mæhle (f. 1956)}

er dr.med., spesialist i medisinsk genetikk og arbeider som overlege.

Forfatter har fylt ut ICMJE-skjemaet og oppgir ingen interessekonflikter.

\section{Steinar Aamdal (f. 1946)}

er spesialist i onkologi, seksjonsoverlege og professor ved Universitetet i Oslo.

Forfatter har fylt ut ICMJE-skjemaet og oppgir ingen interessekonflikter.

\section{Nils A. Eide (f. 1945)}

er spesialist i øyesykdommer og er overlege med hovedansvar for behandling av melanom i øyet.

Forfatter har fylt ut ICMJE-skjemaet og oppgir ingen interessekonflikter.

\section{Henrik L. Svendsen (f. 1978)}

er lege i spesialisering ved Plastikkirurgisk avdeling.

Forfatter har fylt ut ICMJE-skjemaet og oppgir ingen interessekonflikter.

\section{Oddbjørn Straume (f. 1968)}

er dr.med. og spesialist i onkologi. Han arbeider som overlege og har $50 \%$ stilling som førsteamanuensis ved Institutt for indremedisin, Universitetet i Bergen.

Forfatter har fylt ut ICMJE-skjemaet og oppgir følgende interessekonflikter: Han har mottatt honorarer og forskningsstøtte fra Roche, BMS, Pfizer og Pierre Fabre.

\section{Trude E. Robsahm (f. 1966)}

er dr.philos. i kreftepidemiologi og er forsker. Forfatter har fylt ut ICMJE-skjemaet og oppgir ingen interessekonflikter.

\section{Kari D. Jacobsen (f. 1956)}

er dr.med., spesialist i onkologi og er fagansvarlig overlege for malignt melanom.

Forfatter har fylt ut ICMJE-skjemaet og oppgir ingen interessekonflikter.

\section{Lars A. Akslen (f. 1957)}

er dr.med., spesialist i patologi, overlege og professor. Han er leder av Norsk Melanom Gruppe (NMG)

Forfatter har fylt ut ICMJE-skjemaet og oppgir ingen interessekonflikter.

\section{Litteratur}

1. Robsahm TE, Johannesen TB, Bachmann IM et al. Nasjonale retningslinjer for diagnostikk, behandling og oppfølging av maligne melanomer. Oslo: Helsedirektoratet, 2011

2. Balch CM. red. Cutaneous melanoma. St. Louis MO: Quality Medical Pub, 2010

3. Cancer in Norway 2010. Cancer incidence, mortality, survival and prevalence in Norway. Oslo: Kreftregisteret, 2012

4. Abbasi NR, Shaw HM, Rigel DS et al. Early diagno sis of cutaneous melanoma: revisiting the $A B C D$ criteria. JAMA 2004; 292: 2771-6.

5. International Agency for Research on Cancer Working Group on artificial ultraviolet (UV) light and skin cancer. The association of use of sunbed with cutaneous malignant melanoma and other skin cancers: a systemic review. Int J Cancer 2007; 120: $1116-22$

6. Goodson AG, Grossman D. Strategies for early melanoma detection: Approaches to the patient with nevi. J Am Acad Dermatol 2009; 60: 719-35, quiz 736-8

7. Balch CM, Gershenwald JE, Soong SJ et al. Final version of 2009 AJCC melanoma staging and classification. J Clin Oncol 2009; 27: 6199-206.

8. Knappskog S, Geisler J, Arnesen T et al. A novel type of deletion in the CDKN2A gene identified in a melanoma-prone family. Genes Chromosomes Cancer 2006; 45: 1155-63.

9. Molven A, Grimstvedt MB, Steine SJ et al. A large Norwegian family with inherited malignant melanoma, multiple atypical nevi, and CDK4 mutation. Genes Chromosomes Cancer 2005; 44: 10-8.

10. GenoMEL. www.genomel.org (17.7.2013).

11. Hansson J, Bergenmar M, Hofer PA et al. Monitoring of kindreds with hereditary predisposition for cutaneous melanoma and dysplastic nevus syndrome: results of a Swedish preventive program. J Clin Oncol 2007; 25: 2819-24.

12. Sladden MJ, Balch C, Barzilai DA et al. Surgical excision margins for primary cutaneous melanoma. Cochrane Database Syst Rev 2009; nr. 4: CD004835.
13. de Wilt JH, van Akkooi AC, Verhoef C et al. Detection of melanoma micrometastases in sentinel nodes - the cons. Surg Oncol 2008: 17: 175-81.

14. Garbe C, Terheyden P, Keilholz U et al. Treatment of melanoma. Dtsch Arztebl Int 2008; 105: 845-51.

15. Morton DL, Thompson JF, Cochran AJ et al. Sentinel-node biopsy or nodal observation in melanoma. N Engl J Med 2006: 355: 1307-17.

16. Yao K, Balch G, Winchester DJ. Multidisciplinary treatment of primary melanoma. Surg Clin North Am 2009; 89: 267-81, xi. . xi.

17. Kroon HM, Thompson JF. Isolated limb infusion: a review. J Surg Oncol 2009; 100: 169-77.

18. Middleton M, Hauschild A, Thomson D et al. Results of a multicenter randomized study to evaluate the safety and efficacy of combined immunotherapy with interleukin-2, interferon-alpha2b and histamine dihydrochloride versus dacarbazine in patients with stage IV melanoma. Ann Oncol 2007 18: $1691-7$

19. Schadendorf D, Ugurel S, Schuler-Thurner B et al. Dacarbazine (DTIC) versus vaccination with autologous peptide-pulsed dendritic cells (DC) in firstline treatment of patients with metastatic melanoma: a randomized phase III trial of the DC study group of the DeCOG. Ann Oncol 2006. 17. 563-70.

20. Eggermont AM, Kirkwood JM. Re-evaluating the role of dacarbazine in metastatic melanoma: what have we learned in 30 years? Eur J Cancer 2004; 40: 1825-36

21. Middleton MR, Grob JJ, Aaronson N et al. Randomized phase III study of temozolomide versus dacarbazine in the treatment of patients with advanced metastatic malignant melanoma. $\mathrm{J}$ Clin Oncol 2000; 18: 158-66.

22. Hodi FS, Oble DA, Drappatz J et al. CTLA-4 block ade with ipilimumab induces significant clinical benefit in a female with melanoma metastases to the CNS. Nat Clin Pract Oncol 2008; 5: 557-61.

23. Hodi FS, O'Day SJ, McDermott DF et al. Improved survival with ipilimumab in patients with metastatic melanoma. N Engl J Med 2010; 363: 711-23.

24. Wolchok JD, Kluger H, Callahan MK et al. Nivolumab plus ipilimumab in advanced melanoma. N Engl J Med 2013; 369: 122-33.

25. Flaherty KT, Puzanov I, Kim KB et al. Inhibition of mutated, activated BRAF in metastatic melanoma. N Engl J Med 2010; 363: 809-19.

26. Sosman JA, Kim KB, Schuchter L et al. Survival in BRAF V600-mutant advanced melanoma treated with vemurafenib. N Engl J Med 2012; 366 707-14.

27. Chapman PB, Hauschild A, Robert $C$ et al. Improved survival with vemurafenib in melanoma with BRAF V600E mutation. N Engl J Med 2011; 364 : 2507-16

28. Hauschild A, Grob JJ, Demidov LV et al. Dabrafenib in BRAF-mutated metastatic melanoma: a multicentre, open-label, phase 3 randomised controlled trial. Lancet 2012; 380: 358-65.

29. Flaherty KT, Infante JR, Daud A et al. Combined BRAF and MEK inhibition in melanoma with BRAF V600 mutations. N Engl J Med 2012: 367 : $1694-703$

30. Farshad ABG, Burg G, Panizzon R et al. A retrospective study of 150 patients with lentigo maligna and lentigo maligna melanoma and the efficacy of radiotherapy using Grenz or soft X-rays. $\mathrm{Br}$ J Dermatol 2002; 146: 1042-6.

31. Mendenhall WM, Amdur RJ, Grobmyer SR et al. Adjuvant radiotherapy for cutaneous melanoma. Cancer 2008: 112: 1189-96.

Mottatt 30.11. 2012, første revisjon innsendt 13.6. 2013, godkjent 1.8. 2013. Redaktør Are Brean. 